\title{
How is the jaguar Panthera onca perceived by local communities along the Paraguai River in the Brazilian Pantanal?
}

\author{
Grasiela Porfirio, Pedro Sarmento, Stephanie Leal and Carlos Fonseca
}

\begin{abstract}
Rapid habitat conversion, hunting as a retaliatory response to livestock depredation and, potentially, lack of knowledge regarding the species' ecological role are the main factors influencing conservation of the Near Threatened jaguar Panthera onca in the Pantanal wetland of Brazil. Investigation of people's perceptions and attitudes towards a species is an important element of conservation initiatives but most information concerning human perceptions of jaguars in the Pantanal comes from conflict with ranchers, who typically perceive this species negatively as a result of economic losses. No information is available concerning perceptions of the jaguar by other inhabitants, particularly along riversides where the main activity is professional and recreational fishing. We used semistructured questionnaires to interview 50 riverside inhabitants on how they perceive the jaguar and to investigate the influence of education and age on such perceptions compared to local people from rural properties in the Pantanal and other Brazilian biomes. 'Dangerous' was the predominant perception. We found that the negative perceptions of jaguars related to people's safety and not to economic losses from livestock depredation. We highlight environmental education programmes, ecotourism and better strategies to reduce livestock losses as useful tools for minimizing the perception that jaguars are dangerous in all situations.
\end{abstract}

Keywords Brazil, conservation, jaguar, Pantanal, Panthera onca, Paraguai River, perceptions

\section{Introduction}

Covering 200,000 $\mathrm{km}^{2}$, the Brazilian Pantanal wetland is a major stronghold for the Near Threatened jaguar Panthera onca (Caso et al., 2008) in the Americas

Grasiela Porfirio* (Corresponding author), Pedro Sarmento and Carlos FonseCA $\dagger$ Departamento de Biologia and Centro de Estudos do Ambiente e do Mar, Universidade de Aveiro, 3810-193 Aveiro, Portugal E-mail grasiela.porfirio@ua.pt

StePhanie Leal Instituto Homem Pantaneiro, Corumbá, Mato Grosso do Sul, Brazil

*Also at: Instituto Homem Pantaneiro, Corumbá, Mato Grosso do Sul, Brazil $\dagger$ Also at: Universidade Lúrio, Campus de Marrere, Nampula, Mozambique

Received 11 November 2013. Revision requested 26 February 2014.

Accepted 29 April 2014. First published online 14 August 2014.
(Zimmermann et al., 2005) and, currently, the species is heterogeneously distributed in $63 \%$ of this biome (Cavalcanti et al., 2012). However, in the Pantanal most of the jaguar population lives outside protected areas as 95\% of this biome consists of private lands (Crawshaw \& Quigley, 1991; Seidl et al., 2001) where the main economic activity is extensive cattle ranching (Seidl et al., 2001; Cavalcanti \& Gese, 2010). Jaguars have coexisted with humans and their livestock for nearly 200 years in the Pantanal (Crawshaw \& Quigley, 1991; Cavalcanti \& Gese, 2010) and livestock predation is considered one of the main causes of people's intolerance towards this species (Zimmermann et al., 2005; Cavalcanti et al., 2012).

Although the jaguar has been well studied in the Pantanal (Schaller \& Crawshaw, 1980; Crawshaw \& Quigley, 1991, 2002; Dalponte, 2002; Soisalo \& Cavalcanti, 2006; de Azevedo \& Murray, 2007; Cavalcanti \& Gese, 2010; Cavalcanti et al., 2012), little is known about people's perceptions and attitudes towards this felid. The information available mostly concerns the conflict between ranchers and jaguars as a result of livestock depredation (Zimmermann et al., 2005; Santos et al., 2008; Marchini \& Macdonald, 2012). No information exists on the relationship between the jaguar and the traditional communities that live along the main rivers of the Pantanal (the Paraguai, Taquari and Cuiabá) where people subsist mainly on fishing.

Large predators are perceived negatively because people fear being attacked or having livestock predated (Campbell \& Alvarado, 2011; Soto-Shoender \& Main, 2013), and this may be an important component in the socio-economic and environmental contexts of the conservation of the jaguar. In this study we evaluate perceptions of the jaguar among adults in riverside communities along the Paraguai River, from Corumbá to Pantanal Matogrossense National Park. As better informed people tend to fear the jaguar less (Cavalcanti et al., 2010), we sought to answer the following questions: (1) is the perception of the jaguar related to people's level of education and age, and (2) are the perceptions of local riverside people different from those of rural-dwellers whose main activity is cattle ranching, and inhabitants of other Brazilian biomes?

\section{Study area}

The study was carried out during April-June 2011 along c. $400 \mathrm{~km}$ of the Paraguai River from Corumbá to Pantanal 
Matogrossense National Park. This area encompasses the only federally-protected area within the Pantanal and is close to the Amolar mountain ridge (a poorly-known area considered important for biodiversity conservation; MMA, 2007).

The Paraguai River is the main drainage channel of the Pantanal (Calheiros \& Ferreira, 1997), flowing 2,621 km north to south, with 1,693 km lying in Brazil (Innocencio, 1977). The predominant vegetation along the river is gallery forest, which in the most elevated areas is not influenced by the seasonal floods that occur in the Pantanal (Pott, 1982), and flooded fields comprising native grasses (da Silva et al., 2000). The climate is warm, with a dry winter season (Köppen's Aw seasonal regime: tropical wet and dry or savannah climate; Cadavid-Garcia, 1984). Annual rainfall is $800-1,400 \mathrm{~mm}$, of which almost $80 \%$ falls during November-March (da Silva et al., 2000).

The main economic activities along the Paraguai River are recreational and professional fishing (Franco et al., 2013). Cattle-ranching is limited because of seasonal flooding and the small size of riverside properties. Although low in density, several communities occupy the river margins, of which Castelo, Paraguai Mirim, Amolar and Barra do São Lourenço are the most populated. Together, these communities comprise c. 70 extended families, distributed along c. $400 \mathrm{~km}$ of the Paraguai River (Instituto Homem Pantaneiro, unpubl. data).

\section{Methods}

We interviewed riverside communities, using a semistructured questionnaire accompanied by a picture of a jaguar (Conforti \& de Azevedo, 2003; Marker et al., 2003; Santos et al., 2008). We travelled by boat, stopping at residences located along the riverbank and, randomly, at residences located in Castelo, Paraguai Mirim, Amolar and Barra do São Lourenço (Fig. 1). On some occasions we interviewed more than one person from the same family but these interviews were at the same time and the interviewees were separated from each other to avoid bias. The questionnaire comprised open and closed questions to gather information about the interviewee and their perceptions of jaguars, following Santos et al. (2008).

To profile the interviewees we asked for their age, gender, birthplace, time living in the region, profession and level of education. To determine perceptions of the jaguar, we asked three questions: (1) have you ever seen a jaguar? (2) where did you see a jaguar? and (3) what do you think of the jaguar? The first question allowed us to evaluate whether the species is recognizable. Responses to the third question established perceptions of the jaguar, with respondents given the possibility of answering dangerous (i.e. a threat to human life), beautiful or both beautiful and dangerous, which was interpreted as a neutral response (Santos et al., 2008).

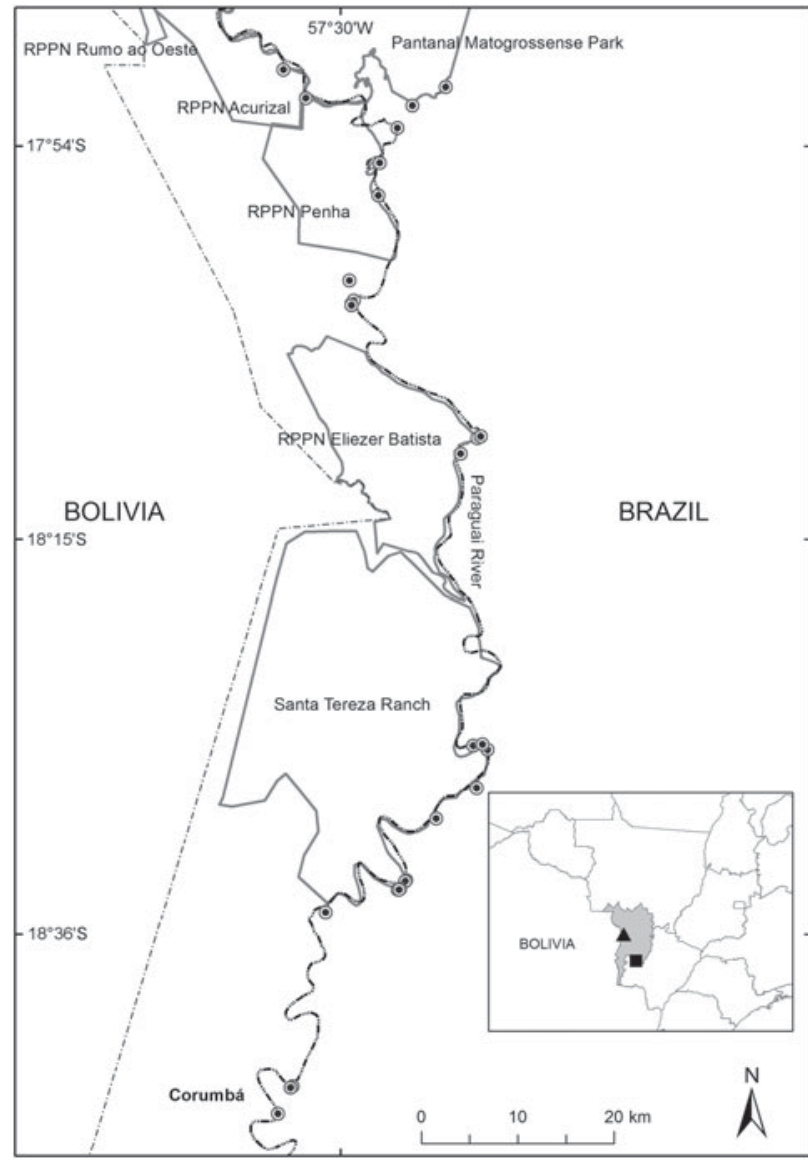

FIG. 1 The study area, showing the communities (circles) where people were interviewed along the Paraguai River in 2011. The inset indicates the location of our study site $(\boldsymbol{\Delta})$ and that of Santos et al. $(2008 ; \boldsymbol{\square})$ in the Pantanal (shaded grey) in Brazil.

A further two questions concerned the values that people attribute to the jaguar: (4) do you think the jaguar should be eliminated from nature? and (5) why? Interviewees could justify either elimination or protection of jaguars (Santos et al., 2008). Responses to these two questions revealed the values associated with jaguars, which were categorized (as in Santos et al., 2008) as: (1) anthropocentric, demonstrating a desire to conserve the jaguar for future generations or believing that the species should be allowed to persist if it does not pose risks to humans; (2) religious, viewing the jaguar as a religious icon; (3) economic, related to economic losses from livestock predation; (4) moral, as jaguars are protected by Brazilian law; or (5) ecological, recognizing the ecological role of the species. Additionally, during interviews, we collected information about the occurrence of jaguar attacks on people in the region.

Analyses were conducted using $R \quad v .2 .15 .3 \quad$ (R Development Core Team, 2009). To test the effect of educational level and age of interviewees we used a General Linear Mixed Model (GLMM). Perceptions were inferred to be positive when the respondent answered 'no' to question 
TABLE 1 Perceptions of the jaguar Panthera onca (as \% of respondents in each study) by riverside inhabitants $(\mathrm{n}=50)$ interviewed in 2011 along the Paraguai River in the Brazilian Pantanal (this study; Fig. 1), by local inhabitants on rural properties in the Miranda subregion of the Pantanal $(n=200)$, and by inhabitants of four other Brazilian biomes $(n=200$; data from Santos et al., 2008, for both latter groups).

\begin{tabular}{llllrrr}
\hline Perception & $\begin{array}{l}\text { Riverside } \\
\text { inhabitants }\end{array}$ & $\begin{array}{l}\text { Rural } \\
\text { inhabitants }\end{array}$ & Amazon & Cerrado & $\begin{array}{c}\text { Atlantic } \\
\text { Forest }\end{array}$ \\
\hline Dangerous & 48.0 & 15.0 & 21.0 & 15.4 & 28.5 & 37.8 \\
Dangerous \& beautiful & 28.0 & 6.0 & 11.2 & 9.0 & 14.5 & 13.4 \\
Beautiful & 24.0 & 71.0 & 60.9 & 68.2 & 37.5 & 39.8 \\
Nothing & 0.0 & 3.5 & 1.5 & 1.0 & 6.0 & 4.0 \\
Other & 0.0 & 3.5 & 5.4 & 6.5 & 0.0 & 2.5 \\
No answer & 0.0 & 1.0 & 0.0 & 0.5 & 0.5 \\
\hline
\end{tabular}

TABLE 2 General Linear Mixed Model examining factors influencing perceptions of the the jaguar, with the respective $\beta$ coefficients (Age and School), by people living along the Paraguai River (Fig. 1). Models are ordered by rank according to their $\triangle$ AIC and weighting (wAIC).

\begin{tabular}{lllllllll}
\hline Model & Intercept & $\beta$ age & $\beta$ school & df & Log likelihood & AICc & $\Delta$ AICc & wAICc \\
\hline Age + School & 0.805 & -0.0094 & 0.118 & 4 & -27.366 & 63.6 & 0.00 & 0.765 \\
Age & 1.111 & -0.009 & & 3 & -30.125 & 66.8 & 3.15 & 0.158 \\
School & 0.4216 & & 0.1146 & 3 & -31.077 & 68.7 & 5.06 & 0.061 \\
Null & 0.660 & & & 2 & -33.589 & 71.4 & 7.81 & 0.015 \\
\hline
\end{tabular}

(4) $(=1)$, and negative when the answer was yes $(=0)$. Educational level was converted to a numeric variable on the scale 1-6: 1 , illiterate; 2 , incomplete fundamental school (i.e. elementary school); 3, complete fundamental school; 4, complete medium school (i.e. high school); 5 , incomplete undergraduate (tertiary education); 6, complete undergraduate. The Akaike information criterion (AIC; Akaike, 1974) was used to evaluate the best model. A $\chi^{2}$ test was used to compare the perceptions (beautiful, dangerous, beautiful and dangerous) and values attributed to the jaguar. These data were also compared to those of inhabitants of rural properties and other Brazilian biomes (Amazon forest, Cerrado, Caatinga and Atlantic Forest), using data from Santos et al. (2008).

\section{Results}

We carried out 50 interviews with local people along the Paraguai River, of which $78 \%$ were men $(n=39)$ and $22 \%$ were women $(n=11)$. Fifty-eight per cent of the interviewees were $20-59$ years old, $32 \% \geq 60$ years old, and $10 \%$ 15-19 years. Most of the riverside inhabitants were born in towns in the Pantanal $(84 \%$ in Corumbá, Poconé, Miranda or Barão do Melgaço), and 14\% were born along the Paraguai River. Only one foreigner (from Germany), who had been living in the region for $>20$ years, was interviewed.

Illiteracy was the most frequent level of education (40\%), followed by incomplete Fundamental School (36\%). Only $10 \%$ of the interviewees had completed Fundamental School and fewer had completed Medium School (8\%). One interviewee had completed tertiary education and another was still studying at the tertiary level.
Subsistence agriculture combined with small-scale cattle ranching were the main professions of the interviewees (24\%), followed by professional fishing, cattle ranching only, housekeeping, property management, cowboy, subsistence agriculture only, live bait collection or boat captain. All of the interviewees confirmed using fish resources from the river as a complementary food source.

All interviewees recognized the jaguar, and 92\% stated that they had seen one in its natural environment. The remainder recognized jaguars from photos, skins or tracks. 'Dangerous' accounted for $48 \%$ of the responses to the question on perceptions, followed by 'dangerous and beautiful' (28\%). 'Beautiful' was the least cited perception of the jaguar. Perceptions differed significantly between riverside people, local people that live on cattle ranches in the Pantanal and inhabitants of other Brazilian biomes $\left(\chi^{2}=102.349, \mathrm{df}=10, \mathrm{P}<0.001\right)$, with a higher proportion of riverside people perceiving the jaguar as dangerous (Table 1).

Age and educational level appeared to influence perceptions of the jaguar along the Paraguai River. Based on the GLMM analysis, the best explanatory model was age + school (Table 2). Older people tended to have negative perceptions about the jaguar $(\mathrm{P}<0.01)$, whereas those with a higher level of education tended to have more positive perceptions of the species $(\mathrm{P}<0.05)$.

Although responses indicated that the jaguar is perceived as a dangerous animal that can kill a person or cause damage to livestock, $66 \%$ of interviewees felt that the jaguar should not be eliminated from nature. The values associated with the jaguar by riverside inhabitants differed significantly from those of local people from ranches and from other Brazilian biomes $\left(\chi^{2}=201.145, \mathrm{df}=20, \mathrm{P}<0.001\right.$; Table 3$)$. 
TABLE 3 Values attributed to the jaguar (as \% of respondents in each study) by riverside inhabitants ( $\mathrm{n}=50$; this study) interviewed along the Paraguai River (Fig. 1), by inhabitants of rural properties in the Miranda subregion of the Pantanal ( $\mathrm{n}=200$ ), and by inhabitants of four other Brazilian biomes $(n=200$; data from Santos et al., 2008 for both latter groups).

\begin{tabular}{|c|c|c|c|c|c|c|}
\hline Value & $\begin{array}{l}\text { Riverside } \\
\text { inhabitants }\end{array}$ & $\begin{array}{l}\text { Rural } \\
\text { inhabitants }\end{array}$ & Amazon & Cerrado & Caatinga & $\begin{array}{l}\text { Atlantic } \\
\text { Forest }\end{array}$ \\
\hline Anthropocentric & 44.0 & 20.5 & 24.4 & 19.4 & 33.5 & 30.8 \\
\hline Ecological & 22.0 & 38.5 & 20.5 & 22.4 & 6.0 & 15.4 \\
\hline Economic & 26.0 & 5.5 & 24.9 & 6.0 & 3.0 & 6.0 \\
\hline Religious & 0.0 & 34.5 & 29.8 & 44.8 & 45.5 & 30.3 \\
\hline Moral & 8.0 & 0.0 & 0.0 & 3.5 & 2.5 & 5.5 \\
\hline Others & 0.0 & 1.0 & 0.5 & 1.5 & 7.0 & 9.5 \\
\hline No answer & 0.0 & 0.0 & 0.0 & 2.5 & 2.5 & 2.5 \\
\hline
\end{tabular}

The predominant reasoning for this was anthropocentric (i.e. protection for future generations), followed by economic and ecological considerations. Three cases of non-fatal jaguar attacks on people were reported by the interviewees in the last 10 years in the region of the Paraguai River.

\section{Discussion}

The conflict between ranchers and jaguars in the Pantanal is well documented and is typically associated with livestock depredation (Zimmermann et al., 2005; Silveira et al., 2008; Cavalcanti \& Gese, 2010; Marchini \& Macdonald, 2012), as occurs elsewhere where domestic livestock coexist with carnivores (Mizutami, 1999; Butler, 2000; Patterson et al., 2004; Rigg et al., 2011). However, this association is not relevant to riverside communities, where cattle ranching is not the main activity. Because of their dependency on river and forest resources such as fish, bait, water, firewood and natural medicines, riverside people are in direct contact with jaguars, which prefer forest habitats proximal to water (Crawshaw \& Quigley, 1991). Thus, it is not surprising that $92 \%$ of the people interviewed had seen a jaguar in its natural habitat. Of the 200 people in the Pantanal interviewed by Santos et al. (2008), in Miranda and Aquidauana, $78 \%$ stated that they had seen a jaguar in its natural environment.

We noted from our interviews that although people viewed the jaguar as a dangerous animal and highlighted the risks to humans, they did not think that the species should be eliminated. We link this to the high incidence of anthropocentric values attributed to the jaguar (riverside communities want future generations to know the species and enjoy its beauty, although they are afraid of the risks it poses to them). The negative perceptions of riverside communities are related to concern for people's safety, whereas for ranchers and local people from rural properties they are predominantly related to the economic damage that the species can cause (although both latter groups also expressed a desire to protect the jaguar; Zimmermann et al., 2005; Santos et al., 2008).
Interviewees highlighted their increased vulnerability to attacks during the wet season, when residences are surrounded by water, forcing inhabitants to move to higher areas that are also favoured by jaguars. This has occurred almost every year since the extensive flood of 1974, which completely changed the environment and socio-economic context of the region as riverside inhabitants could no longer work in the flooded cattle ranches (Franco et al., 2013). Extensive flooding is the major ecological driver in the Pantanal and for most terrestrial mammals, including the jaguar, flooding drastically reduces the area available for foraging (Crawshaw \& Quigley, 1991), making predatory attacks on livestock more frequent when wild prey are not available, as informally reported during the interviews. Therefore, although cattle ranching is not a crucial activity to the interviewees, losses caused by livestock predation still shape perceptions. Similarly, news of jaguar attacks on people spreads quickly, possibly increasing fear and negative perceptions of the jaguar. Three cases of non-fatal jaguar attacks were reported by the interviewees, two (one fatal) were cited by Campos Neto et al. (2011), and a further two were reported during 2013-2014 (G. Porfirio, pers. obs.).

Although jaguars are potentially dangerous to people (Marchini \& Macdonald, 2012), according to Cavalcanti et al. (2010) fear of this species varies depending on people's knowledge. As highlighted by Santos et al. (2008), several studies have proposed environmental education as a tool for mitigating conflict between people and wildlife. Some educational material on coexistence between predators and domestic animals is available (e.g. Marchini \& Luciano, 2008; Marchini et al., 2011). The use of this kind of material, especially in schools located along the Paraguai River, should be promoted, especially as environmental awareness seems to translate more easily into behaviour amongst young students (Carvalho, 2001; Lucherini \& Merino, 2008). The presence of parents at environmental education events in schools could also contribute to awareness in the medium- to long-term, thereby helping to foster a healthier coexistence with jaguars (Damerell et al., 2013). As it has been suggested there is a link between knowledge and positive attitudes towards animals (Cavalcanti et al., 2010; 
Torkar et al., 2010), changes in attitudes could be achieved and attenuated, independently of age or educational level. This could be the most efficient and cost-effective way to work with adults along the Paraguai River, as communities and houses are located far from each other, hindering access. Nevertheless, there are also other strategies, such as ecotourism and improvement of management to minimize livestock predation (Marchini et al., 2011), to help protect the species (Loveridge et al., 2010) and to shape more positive perceptions of the jaguar.

We believe that the feeling of local people living along the Paraguai River that the jaguar needs to be protected is derived from changes in tourism. Even though the main tourism-related activity in the region is recreational fishing rather than ecotourism, there are several cases where people have spent $>_{1}$ hour observing a jaguar on the riverbank (e.g. at Porto Joffre; G. Porfirio, pers. obs.). Jaguar observation needs, however, to be regulated, to limit the risks to both people and jaguars. Currently, only Mato Grosso state in Brazil has a specific law to deal with jaguar observation by tourists, prohibiting jaguar baiting (Consema Resolution 85/2011).

As the Pantanal is currently facing potential changes, especially as a result of habitat conversion (Desbiez et al., 2010), and human activity is the main threat to jaguars (Cavalcanti et al., 2012), understanding how people perceive this species and how they coexist and interact with it and the general environment are essential to ensure the persistence of jaguars along the Paraguai River and elsewhere in the Pantanal.

\section{Acknowledgements}

We are grateful to MMX Mineração e Metálicos, Fundação para Ciência e Tecnologia de Portugal (for a scholarship to GP: SFRH/BD/51033/2010, cofunded by POCI 2010 and FSE), Department of Biology, Aveiro University, Homem Pantaneiro Institute, C.A. Zucco, and John O’Brien for help with English.

\section{References}

Aкаike, H. (1974) A new look at the statistical model identification. IEEE Transactions on Automatic Control, 19, 716-723.

BUtLER, J.R.A. (2000) The economic costs of wildlife predation on livestock in Gokwe Communal lands, Zimbabwe. African Journal of Ecology, 38, 23-30.

Cadavid Garcia, E.A. (1984) O clima no Pantanal Mato-grossense. Embrapa-CPAP, Corumbá, Brazil.

Calheiros, D.F. \& Ferreira, C.J.A. (1997) Alterações limnológicas no rio Paraguai ('dequada') e o fenômeno natural de mortandade de peixes no Pantanal Mato-grossense-MS. Embrapa-CPAP, Corumbá, Brazil.
Campbell, M.O. \& Alvarado, M.E.T. (2011) Public perceptions of jaguars Panthera onca, pumas Puma concolor and coyotes Canis latrans in El Salvador. Area, 43, 250-256.

Campos Neto, M.F., Garrone Neto, D. \& Haddad, Jr, V. (2011) Attacks by jaguars (Panthera onca) on humans in central Brazil: report of three cases, with observations of a death. Wilderness and Environmental Medicine, 22, 130-135.

CARVAlHo, I.C.M. (2001) Qual educação ambiental? Elementos para um debate sobre educação ambiental e extensão rural. Agroecologia e Desenvolvimento Rural Sustentável, 2, 43-51.

Caso, A., Lopez-Gonzalez, C., Payan, E., Eizirik, E., de Oliveira, T., Leite-Pitman, R. et al. (2008) Panthera onca. In IUCN Red List of Threatened Species v. 2014.1. Http://www. iucnredlist.org [accessed 17 June 2014].

Cavalcanti, S.M.C., de Azevedo, F.C.C., Tomás, W.M., Boulhosa, R.L.P. \& Crawshaw, JR, P.G. (2012) The status of the jaguar in the Pantanal. Cat News, 7, 29-34.

Cavalcanti, S.M.C. \& Gese, E.M. (2010) Kill rates and predation patterns of jaguars (Panthera onca) in the southern Pantanal, Brazil. Journal of Mammalogy, 91, 722-736.

Cavalcanti, S.M.C., Marchini, S., Zimmermann, A., Gese, E.M. \& MaCDonald, D.W. (2010) Jaguars, livestock and people: reality and perceptions behind the conflicts in Brazil. In The Biology and Conservation of Wild Felids (eds D.W. Macdonald \& A. Loveridge), pp. 383-402. Oxford University Press, Oxford, UK.

Conforti, V.A. \& de Azevedo, F.C.C. (2003) Local perceptions of jaguars (Panthera onca) and pumas (Puma concolor) in the Iguaçú National Park, south Brazil. Biological Conservation, 111, 215-221.

Crawshaw, JR, P.G. \& Quigley, H.B. (1991) Jaguar spacing, activity and habitat use in a seasonally flooded environment in Brazil. Journal of Zoology, 223, 357-370.

Cranshaw, JR, P.G. \& Quigley, H.B. (2002) Hábitos alimentarios del jaguar y el puma en el Pantanal, Brasil, con implicaciones para su manejo y conservación. In El Jaguar en el nuevo milenio. Una evaluación de su estado, detección de prioridades y recomendaciónes para la conservación de los jaguares en America (eds R.A. Medellin, C. Chetkiewicz, A. Rabinowitz, K.H. Redford, J.G. Robinson, E. Sanderson \& A. Taber), pp. 223-235. Universidad Nacional Autonoma de Mexico/Wildlife Conservation Society, D.F., Mexico.

Dalponte, J.C. (2002) Dieta del jaguar y depredación de ganado em el norte del Pantanal, Brasil. In El Jaguar en el nuevo milenio. Una evaluación de su estado, detección de prioridades y recomendaciónes para la conservación de los jaguares en America (eds R.A. Medellin, C. Chetkiewicz, A. Rabinowitz, K.H. Redford, J.G. Robinson, E. Sanderson \& A. Taber), pp. 209-221. Universidad Nacional Autonoma de Mexico/Wildlife Conservation Society, D.F., Mexico.

Damerell, P., Howe, C. \& Milner-Gulland, E.J. (2013) Child-orientated environmental education influences adult knowledge and household behavior. Environmental Research Letters, 8, 1-7.

Da Silva, M.P., Mauro, R.A., Mourão, G. \& Coutinho, M. (2000) Distribuição e quantificação de classes de vegetação do Pantanal através de levantamento aéreo. Revista Brasileira de Botânica, $47,109-112$.

De Azevedo, F.C.C. \& Murray, D.L. (2007) Spatial organization and food habits of jaguars (Panthera onca) in a floodplain forest. Biological Conservation, 137, 391-402.

Desbiez, A.L.J., Bodmer, R.E. \& Tomas, W.M. (2010) Mammalian densities in a Neotropical wetland subject to extreme climatic events. Biotropica, 42, 372-378.

Franco, J.L.A., Drummond, J.A., Gentile, C. \& Azevedo, A.I. (2013) Biodiversidade e ocupação humana do Pantanal matogrossense. Garamond, Rio de Janeiro, Brazil. 
Innocencio, N.R. (1977) Hidrografia. In Geografia do Brasil (ed. IBGE), pp. 73-90. IBGE, Rio de Janeiro, Brazil.

Loveridge, A., Wang, S.W., Frank, L.G. \& Seindensticker, J. (2010) People and wild felids: conservation of cats and management of conflicts. In Biology and Conservation of Wild Felids (eds D.W. Macdonald \& A. Loveridge), pp. 161-195. Oxford University Press, New York, USA.

Lucherini, M. \& Merino, M.J. (2008) Perceptions of human-carnivore conflicts in the High Andes of Argentina. Mountain Research and Development, 28, 81-85.

Marchini, S., Cavalcanti, S. \& de Paula, R.C. (2011) Predadores silvestres e animais domésticos guia prático de convivência. Instituto Chico Mendes de Conservação da Biodiversidade, Brasília, Brazil.

Marchini, S. \& Luciano, R. (2008) Guia de convivência Gente $e$ Onças. Amazonarum, Alta Floresta, Brazil.

Marchini, S. \& Macdonald, D.W. (2012) Predicting ranchers' intention to kill jaguars: case studies in Amazonia and Pantanal. Biological Conservation, 147, 213-221.

Marker, L.L., Mills, M.G.L. \& Macdonald, D.W. (2003) Factors influencing perceptions of conflict and tolerance toward cheetahs on Namibian farmlands. Conservation Biology, 15, 1290-1298.

Mizutami, F. (1999) Impact of leopards on a working ranch in Laikipia, Kenya. African Journal of Ecology, 37, 211-225.

maA (Ministério do Meio Ambiente) (2007) Áreas prioritárias para a Conservação, Uso Sustentável, e Repartição de Benefícios da Biodiversidade Brasileira. MMA, Brasília, Brazil.

Patterson, B.D., Kasiki, S.M., Selempo, E. \& Kays, R.W. (2004) Livestock predation by lions (Panthera leo) and other carnivores on ranches neighboring Tsavo National Parks, Kenya. Biological Conservation, 119, 507-516.

Ротт, A. (1982) Pastagens nativas e cultivadas das sub-regiões de Nhecolândia e Paiaaguás do Pantanal Matogrossense. Embrapa-CPAP, Corumbá, Brazil.

R Development Core Team (2009) R: A Language and Environment for Statistical Computing. R. Foundation for Statistical Computing. Http://www.R-project.org.

RigG, R., Findo, S., Wechselberger, M., Gorman, M.L., Sillero-Zubiri, C. \& Macdonald, D.W. (2011) Mitigating carnivore-livestock conflict in Europe: lessons from Slovakia. Oryx, 45, 272-280.

Santos, F.R., Jácomo, A.T.A. \& Silveira, L. (2008) Humans and jaguar in five Brazilian biomes: same country, different perceptions. Cat News, 4, 21-25.

Schaller, G.B. \& Crawshaw, Jr, P.G. (1980) Movement patterns of jaguar. Biotropica, 12, 161-168.

Seidl, A.F., Silva, J.S.V. \& Moraes, A.S. (2001) Cattle ranching and deforestation in the Brazilian Pantanal. Ecological Economics, $36,413-425$.

Silveira, L., Boulhosa, R., Astete, S. \& JÁcomo, A.T.A. (2008) Management of domestic livestock predation by jaguars in Brazil. Cat News, 4, 26-30.

Soisalo, M.K. \& Cavalcanti, S.M.C. (2006) Estimating the density of a jaguar population in the Brazilian Pantanal using camera-traps and capture-recapture sampling in combination with GPS radio-telemetry. Biological Conservation, 129, $487-496$

Soto-Shoender, J.R. \& Main, M.B. (2013) Differences in stakeholder perceptions of the jaguar Panthera onca and puma Puma concolor in tropical lowlands of Guatemala. Oryx, 47, 109-112.

Torkar, H., Mohar, P., Gregorc, T., Nekrep, I. \& Adamič, M.H. (2010) The conservation knowledge and attitudes of teenagers in Slovenia toward the Eurasian otter. International Journal of Environmental and Science Education, 5, 341-352.

Zimmermann, A., Walpole, M.J. \& Leader-Williams, N. (2005) Cattle ranchers' attitudes to conflicts with jaguars in the Pantanal of Brazil. Oryx, 39, 1-7.

\section{Biographical sketches}

Grasiela Porfirio's research focuses on carnivore population ecology and human-wildlife coexistence. Pedro Sarmento's research focuses on carnivore population ecology and ecological modelling. He is a member of the IUCN Cat Specialist Group. STEPHANIE LEAL is a geographer. Her work focuses on environmental education. CARLos FonseCa specializes in research on ecology, hunting, wildlife management, conservation and climate change. 